Article

\title{
Seven-Membered Rings through Metal-Free Rearrangement Mediated by Hypervalent Iodine
}

\author{
Siguara Bastos Lemos Silva ${ }^{1}$, Adriana Della Torre ${ }^{2}$, João Ernesto de Carvalho ${ }^{2}$, \\ Ana Lúcia Tasca Gois Ruiz ${ }^{2}$ and Luiz F. Silva, Jr. ${ }^{1, *}$
}

1 Departamento de Química Fundamental, Instituto de Química, Universidade de São Paulo, Av. Prof. Lineu Prestes, 748, CP 26077, São Paulo-SP CEP 05513-970, Brazil; E-Mail: siguara.silva@usp.br

2 Division of Pharmacology and Toxicology, Multidisciplinary Center for Chemical, Biological and Agricultural, State University of Campinas, 6171, Campinas-SP CEP 13081-970, Brazil; E-Mails: adriana_biotec@yahoo.com.br(A.D.T.); carvalho_je@yahoo.com.br (J.E.C.); analucia@cpqba.unicamp.br (A.L.T.G.R.)

* Author to whom correspondence should be addressed; E-Mail: luizfsjr@iq.usp.br; Tel.: +5511-3091-2388; Fax: +5511-3815-5579.

Academic Editor: Derek J. McPhee

Received: 2 December 2014 / Accepted: 8 January 2015 / Published: 15 January 2015

\begin{abstract}
A versatile and metal-free approach for the synthesis of carbocycles and of heterocycles bearing seven- and eight-membered rings is described. The strategy is based on ring expansion of 1-vinylcycloalkanols (or the corresponding silyl or methyl ether) mediated by the hypervalent iodine reagent HTIB (PhI(OH)OTs). Reaction conditions can be easily adjusted to give ring expansion products bearing different functional groups. A route to medium-ring lactones was also developed.
\end{abstract}

Keywords: hypervalent iodine; ring expansion; rearrangement; seven-membered ring; antiproliferative activity

\section{Introduction}

The presence of seven-membered rings in compounds with remarkable biological activity continuously challenges organic chemists to develop efficient method for their preparation [1-14] (for examples of 
natural or designed compounds, see Figure 1). Construction of seven-membered rings is relatively more difficult than the corresponding process for five- and six-membered rings, mainly because cyclization reactions have the inherent drawback of entropic factors and transannular interactions $[1,3,15]$. Nevertheless, a variety of different methodologies were envisioned to circumvent these problems, such as palladium-catalyzed intramolecular reactions, and radical and electrophilic cyclizations [1-4,7,9-12]. Besides the palladium-catalyzed processes, other metal-mediated reactions were investigated and ring-closing metathesis and cycloadditions are probably the most used in the synthesis of seven- and eight-membered rings [5-10,12,16]. Another approach is a ring expansion reaction [12,17-19], which has the main advantage to avoid entropic factors and high-diluted conditions $[1,15]$. One possible strategy to promote a ring expansion is an oxidative rearrangement that can be performed with transition metals, such as palladium(II) [17], mercury(II) [20], and thallium(III) $[21,22]$. An alternative to prevent the use of these metals is a hypervalent iodine reagent that promotes several different reactions in an efficient manner, such as formation of $\mathrm{C}-\mathrm{C}$ bonds, stereoselective oxidations, and many important functional group transformations, including asymmetric reactions [23-30]. Although oxidative rearrangements mediated by hypervalent iodine have been reported in many publications, systematic studies regarding ring expansion reactions are scarce [27]. The ring expansion of methylene derivatives mediated by $\mathrm{PhI}(\mathrm{OH}) \mathrm{OTs}$ (HTIB or Koser's Reagent) has been investigated by Justik and Koser for the synthesis of six-, seven-, and eight-membered ring carbocyclic compounds [31,32]. This protocol was subsequently applied in the total synthesis of both isomers of ar-himachalene (Figure 1) [33]. This article presents a versatile and metal-free approach for the synthesis of molecules bearing a seven-membered ring, through a ring expansion reaction [34].
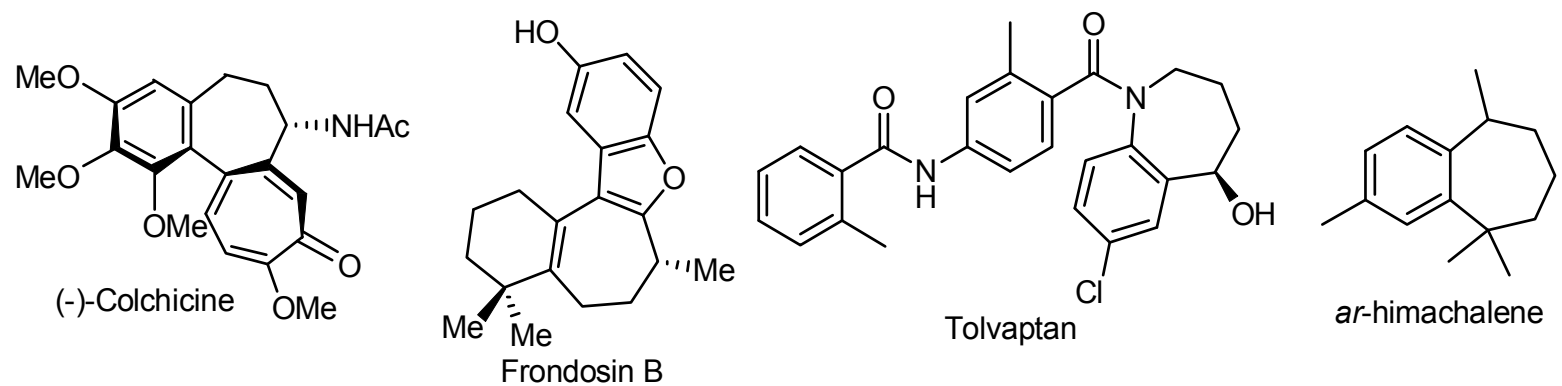

Figure 1. Compounds bearing seven-membered ring fused to aromatic ring.

\section{Results and Discussion}

The substrates required for the ring expansion reactions were prepared in an efficient manner. The reaction of 1-tetralone (1a) with $\mathrm{CH}_{2}=\mathrm{CHMgBr}$ gave the unsaturated 1-tetralol 2a, in $89 \%$ yield [35]. Considering the possible instability of the tertiary benzylic and allylic alcohol $\mathbf{2 a}$, we decided to protect it as the trimethylsilyl (TMS) ether. The protocol using trimethylsilyl chloride/hexamethyldisilazane (TMSCl/HMDS) in reflux of hexane was applied to $\mathbf{2 a}$, giving the desired product $\mathbf{3 a}$ in only $11 \%$ yield. However, using HMDS in the presence of a catalytic amount of $\mathrm{I}_{2}$, as reported by Karimi and Golshani [36], was possible to obtain cleanly 3a in 99\% yield (Scheme 1). 
<smiles>O=C1CCCc2ccccc21</smiles>

1a

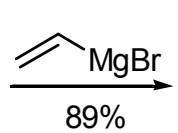<smiles>C=CC1(O)CCCc2ccccc21</smiles>

$2 a$
TMSCI, HMDS: $11 \%$ HMDS, $\mathrm{I}_{2}, \mathrm{CH}_{2} \mathrm{Cl}_{2}: 99 \%$<smiles>C=CC1(O[Na])CCCc2ccccc21</smiles>

$3 a$

Scheme 1. Preparation of the unsaturated TMS ether 3a. HMDS: hexamethyldisilazane and TMSCl: trimethylsilylchloride.

The above two-step sequence was applied to several ketones, leading to $\mathbf{3 b}$-l. We were also interested in the behavior of alkyl ethers. Thus, the methyl ether 4a was prepared treating $\mathbf{2 a}$ with $\mathrm{KOH} / \mathrm{MeI}$ (Figure 2) [37].
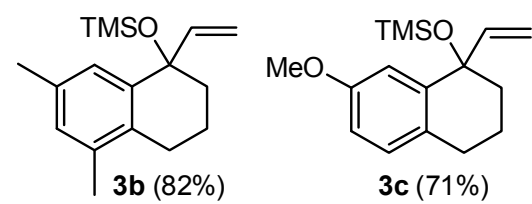<smiles>C=CC1(OC)CCCc2cc(OC)c(OC)cc21</smiles><smiles>C=CC1(OC)CCCc2c(Br)cccc21</smiles><smiles></smiles><smiles>C=CC1(OC)CCOc2ccccc21</smiles><smiles>C=CC1(O[Na])CCCc2c(OC)cccc21</smiles><smiles>C=CC1(OC)CCCc2cc(OC)ccc21</smiles><smiles>C=CC1(O[Na])CCC(C)c2ccccc21</smiles><smiles>C=CC1(OC)CCCCc2ccccc21</smiles><smiles>C=CC1(O[Na])CC[SH](C)(=O)c2ccccc21</smiles><smiles>C=CC1(O[Na])CCN(S)c2ccccc21</smiles>

Figure 2. Structure of substrates $\mathbf{3 b}-\mathbf{l}$ and $\mathbf{4 a}$.

We first performed a detailed investigation on the reactivity of the TMS-protected 1-vinylcycloalkanol 3a. Thus, treatment of $3 \mathrm{a}$ with $\mathrm{HTIB}$ in $\mathrm{CH}_{3} \mathrm{CN}$, in trimethylorthoformiate or without solvent [38] led to a complex mixture of compounds. Fortunately, when the unsaturated TMS-ether 3a was treated with HTIB in $\mathrm{MeOH}$ [31] in the presence of $p-\mathrm{TsOH}$, thin layer chromatography (TLC) analysis indicated the cleavage of the labile TMS-group. Then, the alcohol 2a formed in the medium reacted with iodine(III), giving the ring expansion product 5a, in 60\% yield (Table 1, Entry 1). The methoxy-ketone 5a would be originated from 3a in four steps. The first would be the acid-catalyzed deprotection of the TMS group, giving $\mathbf{2 a}$, on which the electrophilic addition of iodine(III) to the double bond would give the cation 9. Migration of the aryl carbon would lead to $\mathbf{1 0}$. A reductive solvolysis on $\mathbf{1 0}$ would produce the methoxylated ketone 5a (Scheme 2). On this step occurs the highly favorable transformation of the hypervalent iodine into the normal valency compound $\mathrm{PhI}$. Higher temperatures and longer reaction times promote an acid-catalyzed elimination of $\mathrm{MeOH}$ from $\mathbf{5 a}$, furnishing the enone $\mathbf{6 a}$, together with the dimer 7a (entry 2). TLC analysis showed that 7a is formed after the work-up. This result is slightly different from that using Tl(III), which gives only the enone 6a from 3a [22]. 
Table 1. HTIB-Mediated Ring Expansion of 3a. HTIB: [Hydroxy(tosyloxy)iodo]benzene; p-TsOH: $p$-Toluenesulfonic acid.

\begin{tabular}{|c|c|c|}
\hline Entry & Conditions & Product (Yield) \\
\hline 1 & 1.0 equiv HTIB, $20 \mathrm{~mol} \% p$-TsOH, $\mathrm{MeOH},-72{ }^{\circ} \mathrm{C}$ to rt, $2 \mathrm{~h}$ & \\
\hline 2 & 1.0 equiv $\mathrm{HTIB}, \mathrm{MeOH},-72$ to $30^{\circ} \mathrm{C}, 2.5 \mathrm{~h}$ & \\
\hline 3 & (1) 1.0 equiv HTIB, $\mathrm{MeOH},-72$ to $30{ }^{\circ} \mathrm{C}, 2.5 \mathrm{~h}$; (2) 2 weeks & \\
\hline 4 & 2.5 equiv $\mathrm{HTIB}, \mathrm{MeOH}, \mathrm{rt}, 2 \mathrm{~h}$ & \\
\hline
\end{tabular}
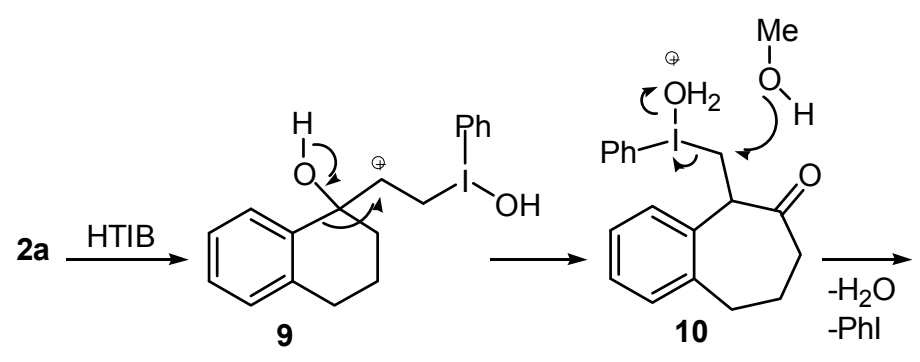

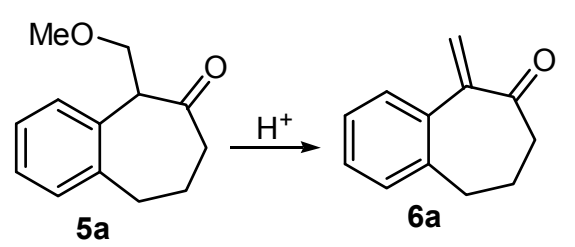

Scheme 2. Mechanism of the Ring Expansion of 2a. HTIB: [Hydroxy(tosyloxy)iodo]benzene.

On standing, the mixture $\mathbf{6 a} / 7 \mathbf{a}$ gave pure crystals of $7 \mathbf{a}$, in $55 \%$ yield from $\mathbf{3 a}$ (Table 1, entry 3 ), whose structure was assigned by $\mathrm{X}$-ray analysis [34]. The pentacyclic compound 7a is formed from the 1-vinylcycloalkanol derivative 3a in a single operation through a tandem ring-expansion/ hetero-Diels-Alder reaction [39,40]. We envisioned that 7 a could be used to obtain a medium ring lactone [41,42]. Indeed, the oxidative cleavage of the double bond of 7 a could be performed with $\mathrm{RuCl}_{3} / \mathrm{NaIO}_{4}$, giving the eleven-membered ring keto-lactone 11a (Scheme 3). In summary, the commercially available 1-tetralone (1a) was transformed in only four steps into 11a, which bears a spiro seven-membered ring and a medium-ring lactone. Thus, in this short sequence of steps, the molecular complexity is greatly increased, because several reactions took place in a few operations. 


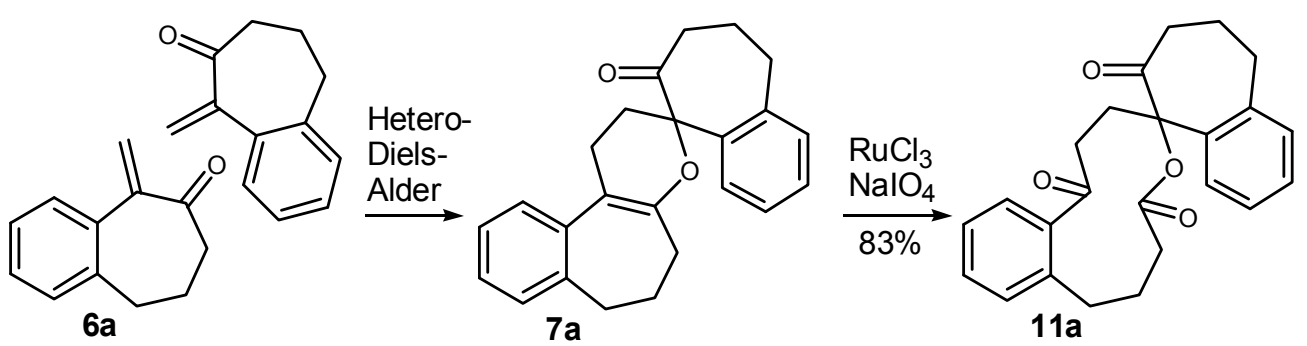

Scheme 3. Preparation of the Medium-Ring Keto-Lactone 11a.

Since the double bond of enone $\mathbf{6 a}$ is prone to further oxidation, we decided to investigate the reaction of 3a with excess of oxidant. When 3a was treated with 2.5 equiv of HTIB, a tandem ring expansion/addition of $\mathrm{MeOH}$ gave the dimethoxy-ketone 8a (Table 1, entry 4). An iodine(III)-mediated electrophilic addition of $\mathrm{MeOH}$ to the enone 6a would give 8a. In summary, different ring expansion products $5 \mathbf{a}-\mathbf{8 a}$ can be obtained from the same substrate (3a) by modification of the reaction conditions.

After exploring the oxidation of 3a with iodine(III) under several conditions, we checked if the protection as a silyl ether was really required. The desired dimethoxy-ketone 8a was also obtained when either 2a or 4a were treated with HTIB (Scheme 4). In conclusion, the presence of the TMS group is not essential for the ring expansion, although higher yields of the desired product were observed from 3a (75\%) than from 2a or from 4a (65\%-67\%). However, the protection of the tertiary benzylic and allylic alcohol 3a as a TMS ether greatly facilitate the storage of the substrate and we decide to do this for all substrates.

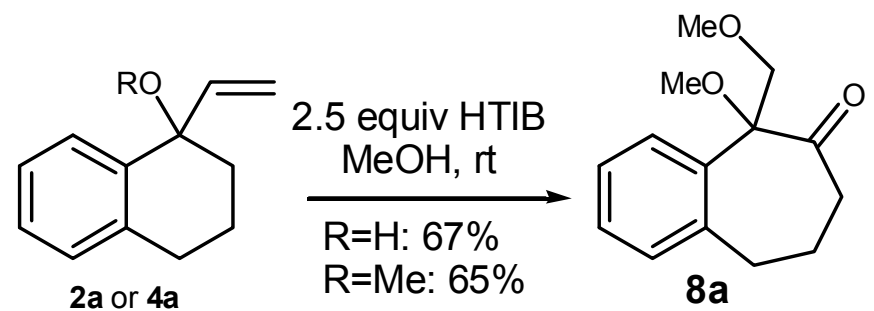

Scheme 4. Tandem Expansion/Addition of 2a and 4a by HTIB. HTIB: [Hydroxy(tosyloxy)iodo]benzene.

A substituent in the aromatic ring can alter the migratory aptitude of the migrating carbon, which may influence the yield of the rearrangement product. For example, a correlation between yield of the product and migratory aptitude was noted by us in Tl(III)-mediated ring contraction of 1,2-di-hydronaphthalenes [43]. Thus, we investigated the ring expansion of $\mathbf{3}$ with different groups in the aromatic ring. Alkyl groups in the aromatic ring can be problematic in reactions with hypervalent iodine [44,45]. Fortunately, the TMS-protected alcohol 3b, which bears methyl groups, gave the dimethoxy ketone 8b (Table 2, Entry 1) in a similar yield to the non-substituted substrate 3a. A methoxy group at the meta position could decrease the migratory aptitude of the migrating carbon. The value of the Hammett constant $\rho_{\mathrm{m}}$ for OMe is 0.11 . Hence, a lower yield of the ring expansion product could be expected. However, the reaction of $\mathbf{3 c}-\mathbf{d}$ with HTIB led to the corresponding ring expansion products 8c-d, respectively, in comparable yield (Entries 2 and 3). A methoxy group in the para position of the migrating carbon increases the migratory aptitude, which could accelerate the rearrangement. In our experience, this is usually a beneficial effect $[43,46]$. However, the reaction with 
3e gave the ring expansion product 8e, in only $10 \%$ yield (entry 4). After some experimentation, we found that treating $3 \mathbf{e}$ with HTIB in a mixture of AcOEt/MeOH gave $\mathbf{8 e}$, in $67 \%$ yield (Entry 5).

Table 2. HTIB-Promoted Tandem Ring Expansion/Addition in MeOH. HTIB: [Hydroxy(tosyloxy)iodo]benzene; TMS: trimethylsilyl.

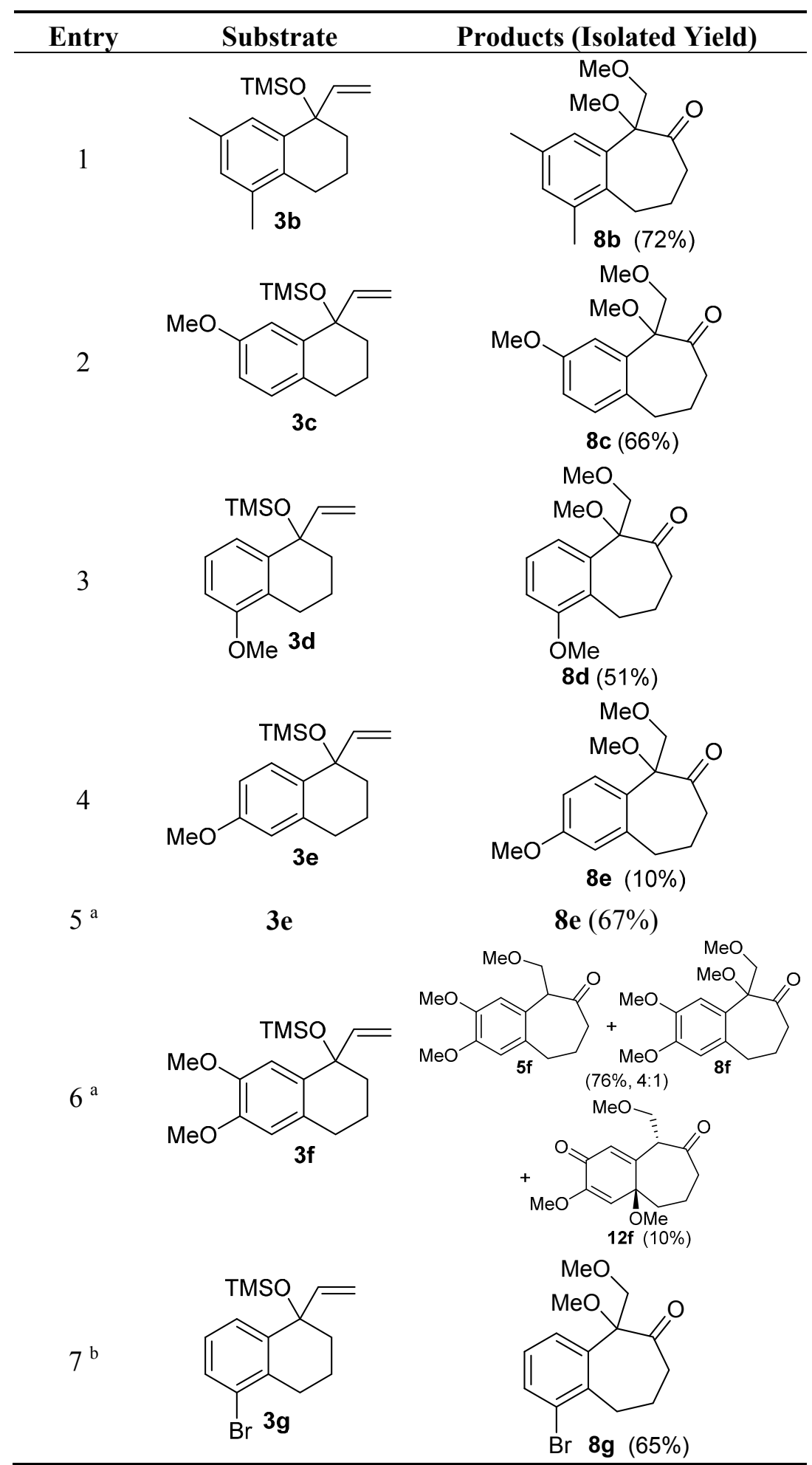


Table 2. Cont.

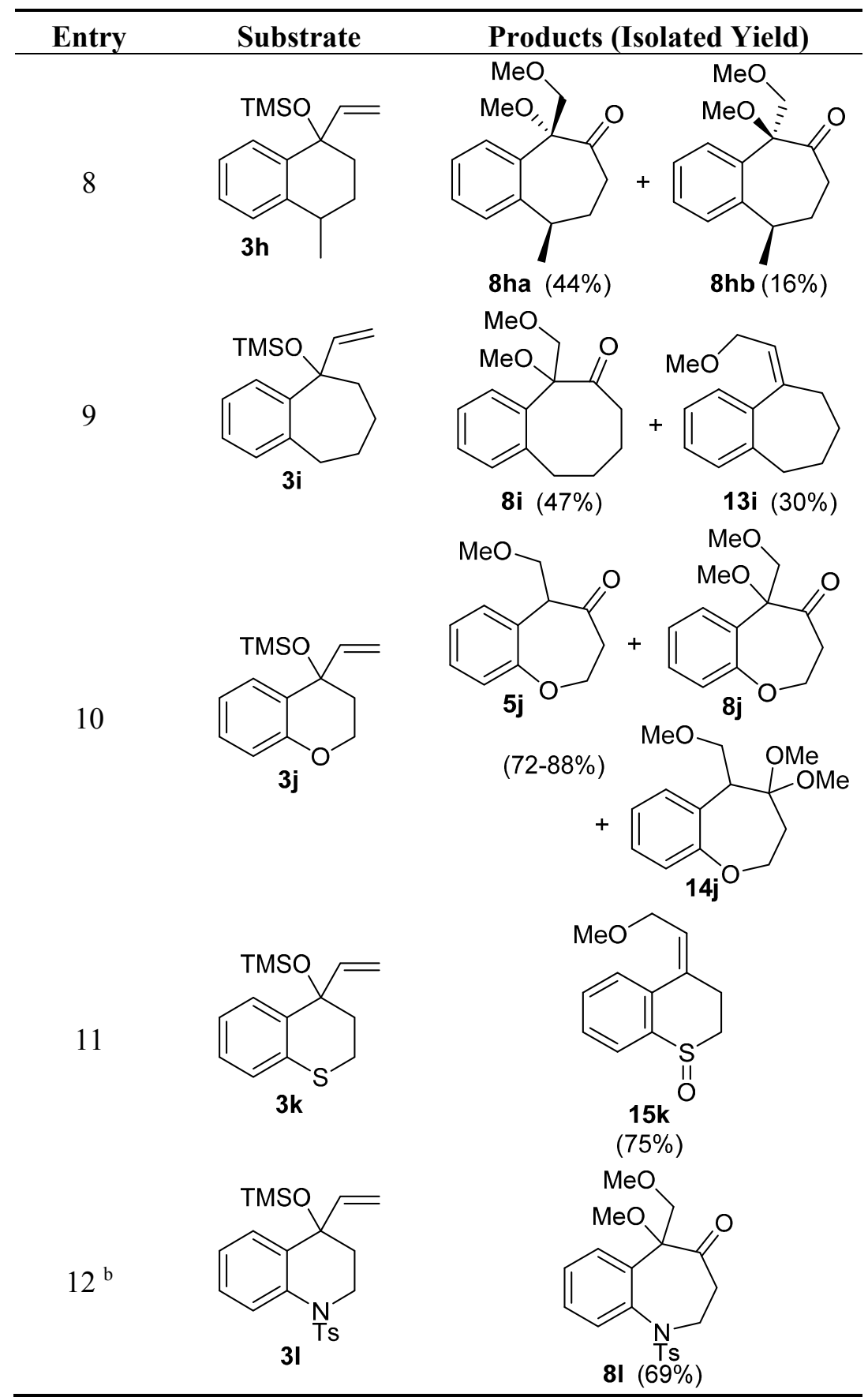

${ }^{\mathrm{a}} \mathrm{AcOEt} / \mathrm{MeOH}(2: 1),-72{ }^{\circ} \mathrm{C}-\mathrm{rt} ;{ }^{\mathrm{b}} \mathrm{MeOH}, 0-50{ }^{\circ} \mathrm{C}$.

The same solvent mixture $(\mathrm{AcOEt} / \mathrm{MeOH})$ was also used in the reaction of $\mathbf{3 f}$. In this case, a mixture of the seven-membered ring compounds $\mathbf{5 f}, \mathbf{8 f}$ and $\mathbf{1 2 f}$ were isolated in very good overall yield (Entry 6). Compounds $\mathbf{5 f}$ and $\mathbf{8 f}$ could not be separated from each other by chromatography column or HPLC. The proposed mechanism for the formation of $\mathbf{1 2 f}$ was based on desaromatization reactions previously described in literature $[47,48]$ (Scheme 5). The first step is the transformation of $\mathbf{3 f}$ into the seven-membered ring compound $\mathbf{5 f}$, as shown in (Scheme 2), followed by the formation of the charge transfer complex $\mathbf{1 6}$ from $\mathbf{5 f}$ and HTIB. A single-electron-transfer (SET) oxidation of $\mathbf{1 6}$ yields the cation radical 17. Species 17 suffers a $\mathrm{MeOH}$ attack from the less hindered convex face and at less hindered carbon 4a (Figure 3), giving the radical 18. A second SET leads to carbocation 19, which 
reacts with the solvent yielding $\mathbf{2 0}$. The enone $\mathbf{1 2 f}$ is formed after an acid hydrolysis of $\mathbf{2 0}$ catalyzed by acid. The relative configuration of $\mathbf{1 2 f}$ was assigned by NMR analysis, including NOESY, HMBC and HSQC (see Supplementary Informationfor details).

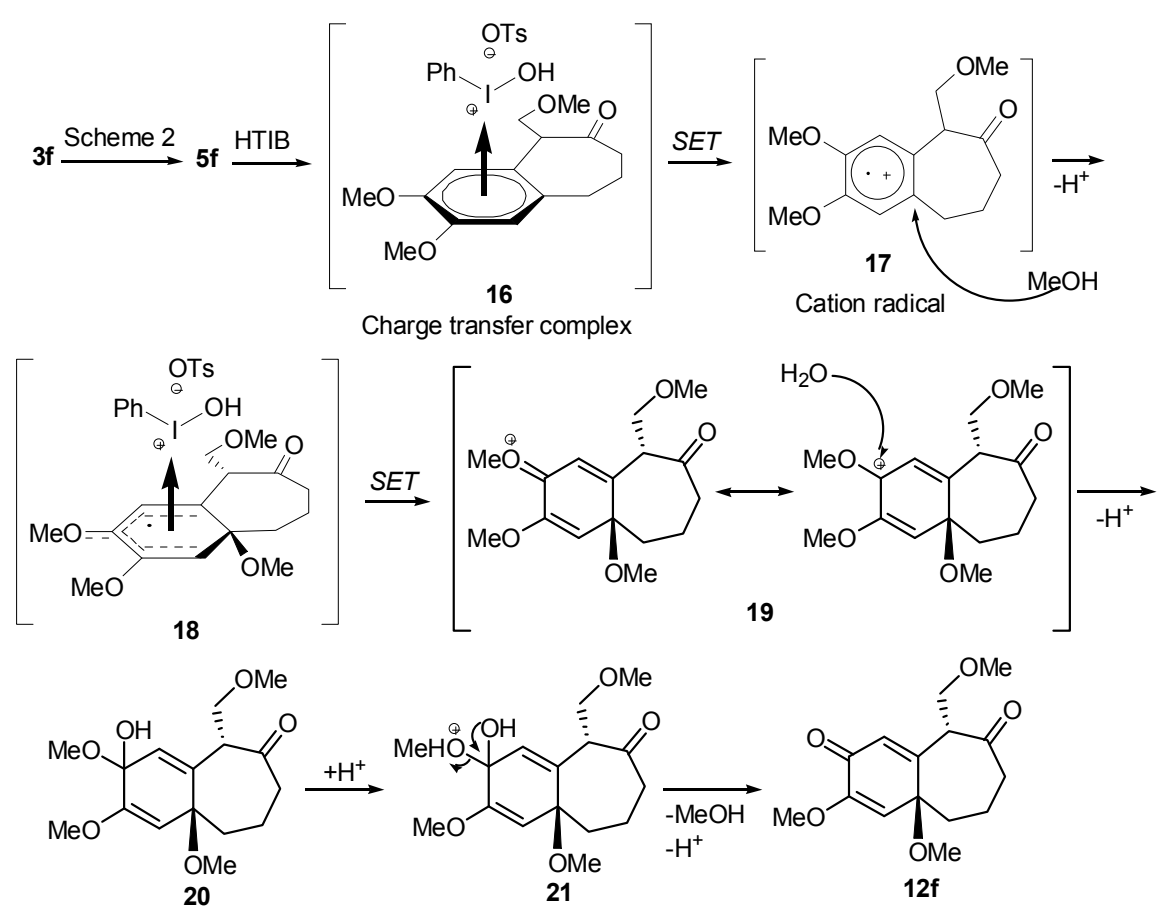

Scheme 5. Mechanism for the Formation of $\mathbf{1 2 f}$.

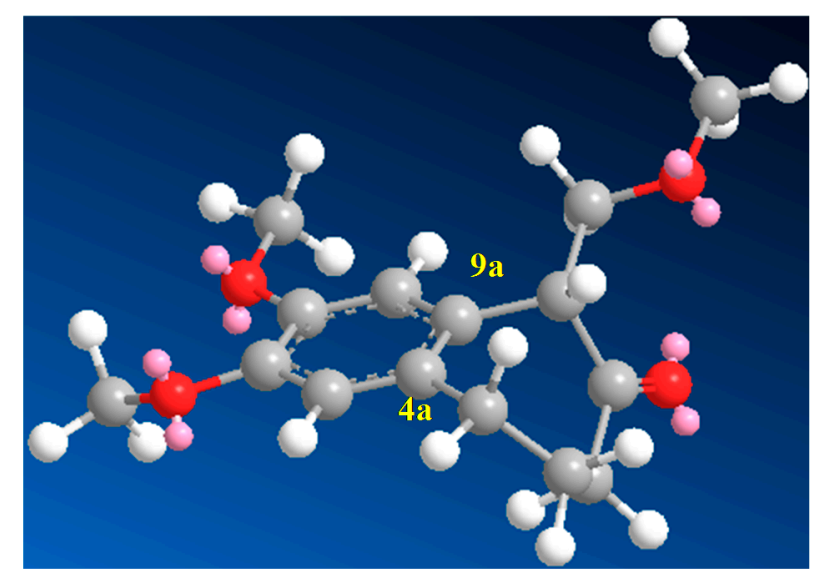

Figure 3. Structure of 17.

The reaction of the bromo-substituted substrate $3 \mathrm{~g}$ with HTIB needed heating until $50{ }^{\circ} \mathrm{C}$ to furnish the ring expanded product in good yield (Table 2, Entry 7). As expected, a withdrawing group as bromide in meta position to migrating carbon decreases its aptitude to migration and, thus, more energetic conditions were necessary. Substrate $3 \mathrm{~h}$ was exposure to HTIB giving 8 ha/b in 44 and 16\%, respectively (Entry 8 ). The stereoselectivity is determined in the electrophilic addition of iodine(III) to the enone 22. This step occurs preferentially through the less hindered face (Scheme 6). 


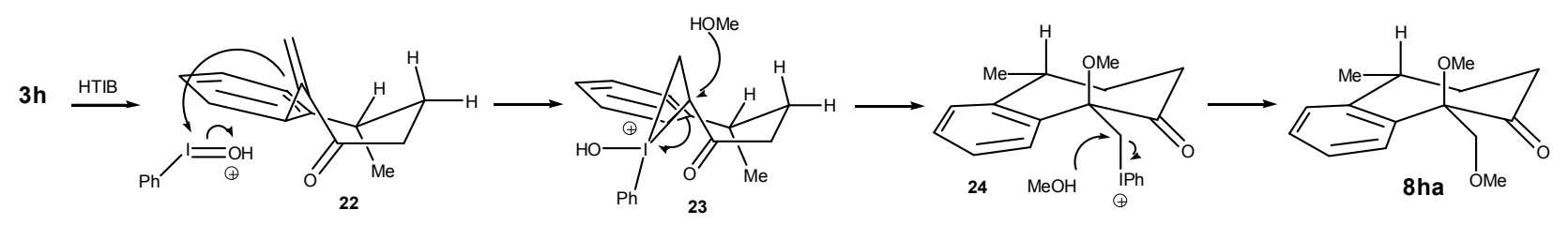

Scheme 6. Mechanism for the Formation of $8 \mathrm{ha}$.

The possibility of using a ring expansion reaction to prepare eight-membered rings was also investigated. Substrate 3i was treated with HTIB, giving the desired eight-membered ring compound $\mathbf{8 i}$ in $47 \%$ yield, together with the unsaturated ether $\mathbf{1 3 i}$ (entry 9). The relative configuration of $\mathbf{1 3 i}$ was assigned based on NMR data of related compounds [49]. This route can be useful to obtain eight-membered ring derivatives, because only three steps are necessary to obtain $\mathbf{8 i}$ from the commercially available benzosuberone. The first step in the formation of 20i (Scheme 7) is a ligand exchange from HTIB with 25, giving 26. A sequence of protonation of $\mathbf{2 6}$ and dehydration of $\mathbf{2 7}$ lead to $\mathbf{2 8}$, that participates in a $\mathrm{S}_{\mathrm{N}} 2$ ' reaction with the solvent, yielding $\mathbf{2 0 i}$.
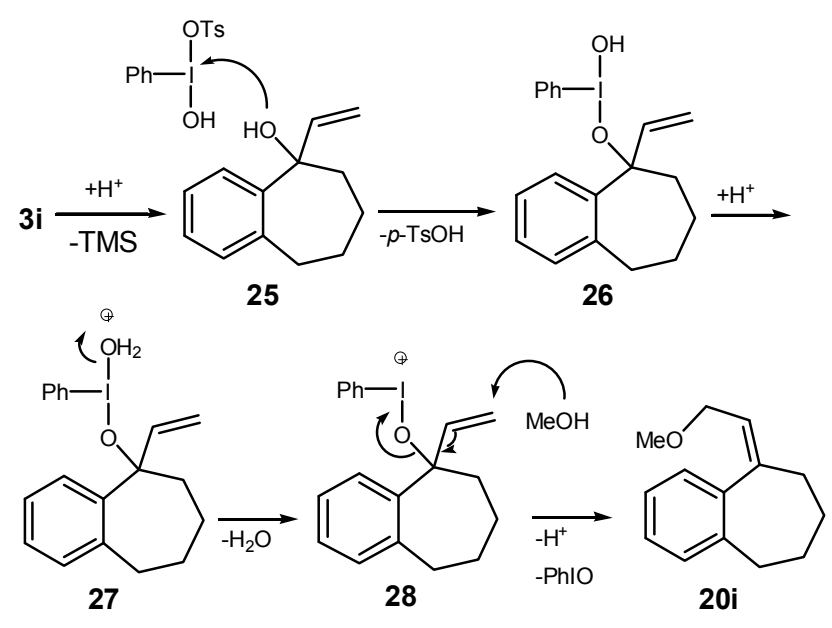

Scheme 7. Mechanism for the Formation of 20i.

The reactivity of heterocyclic substrates was also examined. When compound $\mathbf{3 j}$ was treated with HTIB, the ring expansion reaction also took place. However, an inseparable mixture of seven-membered ring $O$-heterocycles5j, $\mathbf{8 j}$, and $\mathbf{1 4 \mathbf { j }}$ was isolated (Table 2, Entry 10). The oxygen at the ortho position of the migrating carbon $\mathbf{8 j}$ change the reactivity, as observed in other oxidative rearrangements promoted by iodine(III) [50]. Treatment of the sulfur derivative $\mathbf{3 k}$ with HTIB gave exclusively the sulfoxide, in $75 \%$ yield (Table 2 , entry 11). The first reaction is the oxidation of the sulfide moiety to the corresponding sulfoxide [51]. This electron-withdrawing group would decrease the migratory aptitude of the migrating carbon and the $\mathrm{S}_{\mathrm{N}} 2$ ' reaction became the favorable pathway. The reaction of substrate $\mathbf{3 1}$ with HTIB furnished the benzazepine $\mathbf{8} \mathbf{I}$ in good yield (Table 2, Entry 12). Structures like $\mathbf{8 1}$ are present in many natural products [52] and have different biological activities [53-56], being important building blocks for drugs. Among the methodologies for the preparation of benzazepines [57-62], metals are involved in most of them and a metal free approach could be a useful alternative, specially for pharmaceuticals applications. 
The antiproliferative activity of seven-membered rings products $(\mathbf{5 f}+\mathbf{8 f}, \mathbf{8 d}, \mathbf{8 g}, \mathbf{1 2 f}$ and $\mathbf{8 l})$ was evaluated against a panel of nine human tumor cell lines and one immortalized human cell line using a protocol described in the literature $[63,64]$. This methodology aims to evaluate a group of samples in many different tumor cell lines to find evidence of their antiproliferative profile. In order to prioritize further evaluations, a threshold for mean logTGI (Total Growth Inhibition) values (mean $\log$ TGI $\leq 1.50$ ) was assumed [65].

Compounds $\mathbf{5 f}+\mathbf{8 f}, \mathbf{8 g}$ and $\mathbf{8 I}$ can be classified as inactive considering the average antiproliferative effect (mean $\log$ TGI $>1.50$ ) (Table 3 ). The mixture $\mathbf{5 f}+\mathbf{8 f}(1: 1)$ showed a selective growth inhibitory effect against glioma (U251, TGI $\left.=4.8 \mu \mathrm{g} \cdot \mathrm{mL}^{-1}\right)$ and prostate $\left(\mathrm{PC}-3\right.$, TGI $\left.=3.6 \mu \mathrm{g} \cdot \mathrm{mL}^{-1}\right)$ cell lines. Moreover, compounds $\mathbf{1 2 f}$ and $\mathbf{8 d}$ showed, respectively, a moderate (mean $\log \mathrm{TGI}=1.03$ ) and a weak $($ mean $\log$ TGI $=1.35)$ citostatic effects. This suggests that the presence of methoxy groups in the ring fused to the seven-membered system can contribute to the antiproliferative activity and the inclusion of a methoxy group on the carbon of the ring fusion can increase this effect.

Table 3. Antiproliferative activities (TGI, $\mu \mathrm{g} \cdot \mathrm{mL}^{-1}$ ) of ring expansion products ${ }^{\text {a }}$.

\begin{tabular}{ccccccc}
\hline & & & & & \\
\end{tabular}

a Tumor human cell lines: U251 (glioma); UACC-62 (melanoma); MCF-7 (breast); NCI-ADR/RES (ovarian resistant to multiple drugs); 786-0 (kidney); NCI-H460 (lung, non small cells); PC-3 (prostate); HT29 (colon); K562 (leukemia). Immortalized non-tumoral cell line: HaCat (human keratinocyte).

\section{Experimental Section}

\section{General Information}

HTIB, HMDS and MeOH were used as received. THF (tetrahydrofuran) was freshly distilled from sodium/benzophenone, $\mathrm{CH}_{2} \mathrm{Cl}_{2}$ was distilled from $\mathrm{CaH}_{2}$ and stored with molecular sieves $3 \AA$. Vinyl magnesium bromide was purchased from Aldrich or prepared from vinyl bromide and magnesium turnings [66]. 1-Tetralone was distilled before used (bp: $\sim 155^{\circ} \mathrm{C}, 32 \mathrm{mmHg}$ ). Column chromatography was performed using silica gel 200-400 Mesh. TLC analyses were performed in silica gel $60 \mathrm{~F}_{254}$ plates, using $\mathrm{UV}, \mathrm{I}_{2}, p$-anisaldehyde, or phosphomolybdic acid solution for visualization. ${ }^{1} \mathrm{H}$ - and 
${ }^{13} \mathrm{C}-\mathrm{NMR}$ spectra were recorded on Bruker (Billerica, MA, USA) or Varian spectrometers (Palo Alto, CA, USA). IR spectra were measured on a Perkin-Elmer 1750-FT (Waltham, MA, USA). Gas chromatography analyses were performed in a HP-6890 series II (Agilent, Santa Clara, CA, USA) and/or Shimadzu-2010 (Kyoto, Japan). Melting points were done in Büchi Melting Point B-545 (Flawil, Switzerland) and are uncorrected. HRMS analyses were performed on a Bruker Daltonics Microtof Eletrospray (Billerica, MA, USA). CHN analyses were performed with Perkin-Elmer CHN 2400 equipment (Waltham, MA, USA). The percentage of bromine in the organic compounds was determined by volumetric titration using a solution of $\mathrm{Hg}\left(\mathrm{NO}_{3}\right)_{2}$ and diphenylcarbazone as indicator. The tests with KI paper were performed applying a drop of the reaction mixture in a filter paper previously impregnated with a solution of KI (10\%), which was dried at $100{ }^{\circ} \mathrm{C}$. The preparation of compounds $\mathbf{3 b}-\mathbf{c}$ and $\mathbf{3 h}-\mathbf{k}$ was reported in the previous communication [34].

1-Tosyl-2,3-dihydroquinolin-4(1H)-one (11). To a mixture of 1,2,3,4-tetrahydroquinoline $(3.7 \mathrm{~mL}, 4.0 \mathrm{~g}$, $30 \mathrm{mmol})$ in anhydrous pyridine $(15 \mathrm{~mL})$, was added $\mathrm{TsCl}(7.63 \mathrm{~g}, 40.0 \mathrm{mmol}, 1.3 \mathrm{equiv})$ at rt. The mixture was stirred at $60{ }^{\circ} \mathrm{C}$ for $15.5 \mathrm{~h}$. The temperature was increased to $110{ }^{\circ} \mathrm{C}$ and the mixture was stirred for $5.5 \mathrm{~h}$. The reaction mixture was cooled to $-5{ }^{\circ} \mathrm{C}$ and hot $\mathrm{H}_{2} \mathrm{O}(25 \mathrm{~mL})$ was added, precipitating the crude product, which was filter under reduced pressure. The solid was washed with $\mathrm{HCl}$ ( $\left.0.01 \mathrm{~mol} \cdot \mathrm{L}^{-1}\right)$ and $\mathrm{H}_{2} \mathrm{O}$, and dried in the air. The small and brownish crystals $(9.808 \mathrm{~g})$ were recrystallized with $\mathrm{MeOH}(200 \mathrm{~mL})$, giving colorless crystals of 1-tosyl-1,2,3,4-tetrahydroquinoline [67] (7.15 g, 24.9 mmol, 83\%). mp: 94.6-95.2 ${ }^{\circ} \mathrm{C}$ (lit.[67]: 91-92 ${ }^{\circ} \mathrm{C}$ ).To a solution of 1-tosyl-1,2,3,4tetrahydroquinoline $(1.56 \mathrm{~g}, 5.00 \mathrm{mmol})$ in acetone $(22.5 \mathrm{~mL})$ at $0{ }^{\circ} \mathrm{C}$ was added anhydrous $\mathrm{MgSO}_{4}$ ( $1.51 \mathrm{~g}, 12.5 \mathrm{mmol}, 2.5$ equiv) and $\mathrm{H}_{2} \mathrm{O}$ (9.0 mL). Subsequently, $\mathrm{KMnO}_{4}$ (4.35 g, 27.5 mmol, 5.5 equiv) was added dropwise for $30 \mathrm{~min}$. The mixture was stirred for $27 \mathrm{~h}$ at $\mathrm{rt}$. The solid was filtered under reduced pressure, washed with $\mathrm{CH}_{2} \mathrm{Cl}_{2}$ and $\mathrm{H}_{2} \mathrm{O}$. Saturated solution of $\mathrm{K}_{2} \mathrm{~S}_{2} \mathrm{O}_{5}(50 \mathrm{~mL})$ was added to the resulting solution. The solid was filtered under reduced pressure. The solution was extracted with $\mathrm{CH}_{2} \mathrm{Cl}_{2}$, washed with brine, and dried with anhydrous $\mathrm{MgSO}_{4}$. The solvent was removed under reduced pressure, giving 11 [68], as white crystals (1.18 g, $3.93 \mathrm{mmol}, 79 \%)$. mp 141.1-141.9 ${ }^{\circ} \mathrm{C}$ (lit. [69] $\left.141-142^{\circ} \mathrm{C}\right)$.

5-Methoxy-1-vinyl-1,2,3,4-tetrahydronaphthalen-1-ol (2d). General Procedure for the Preparation of Allylic Alcohols. To a solution of 5-methoxy-1-tetralone (3.52 g, $20.0 \mathrm{mmol})$ in anhydrous THF $(20 \mathrm{~mL})$ in a Schlenk flask, was added $\mathrm{CH}_{2}=\mathrm{CHMgBr}$ in THF $\left(1 \mathrm{~mol} \cdot \mathrm{L}^{-1}, 50.0 \mathrm{~mL}, 50.0 \mathrm{mmol}\right)$ at $0{ }^{\circ} \mathrm{C}$. The mixture was stirred for 3-4 h at rt. Saturated solution of $\mathrm{NH}_{4} \mathrm{Cl}(32 \mathrm{~mL})$ was added dropwise at $0{ }^{\circ} \mathrm{C}$. The aqueous phase extracted with AcOEt, dried under anhydrous $\mathrm{MgSO}_{4}$, filtered, and the solvent was removed under reduced pressure. The crude product was purified by flash column chromatography (hexanes/AcOEt, 4:1), giving 2d (2.97 g, $14.6 \mathrm{mmol}, 73 \%$ ), as colorless oil. IR (film) v/cm ${ }^{-1} 1257$, 1467, 1583, 2938, 3430; ${ }^{1} \mathrm{H}-\mathrm{NMR}\left(300 \mathrm{MHz}, \mathrm{CDCl}_{3}\right) \delta 1.79-1.98(\mathrm{~m}, 5 \mathrm{H}), 2.53-2.83(\mathrm{~m}, 2 \mathrm{H}), 3.82$ (s, $3 \mathrm{H}), 5.19(\mathrm{dd}, 1 \mathrm{H}, J=1.7,10.8), 5.29(\mathrm{dd}, 1 \mathrm{H}, J=1.7,17.1), 6.04(\mathrm{dd}, 1 \mathrm{H}, J=10.8,17.1), 6.75$ (dd, $1 \mathrm{H}, J=0.9,8.1), 7.00-7.03(\mathrm{~m}, 1 \mathrm{H}), 7.17(\mathrm{t}, 1 \mathrm{H}, J=8.1) ;{ }^{13} \mathrm{C}-\mathrm{NMR}\left(75 \mathrm{MHz}, \mathrm{CDCl}_{3}\right) \delta 18.5,23.2$, $37.3,55.4,73.3,108.5,113.1,119.7,126.2,126.4,141.0,144.8,156.9$; LRMS $m / z(\%) 63(18), 115$ (98), 128 (54), 141 (58), 155 (65), 171 (55), 186 (100); HRMS (ESI) m/z, calcd for $\left[\mathrm{C}_{13} \mathrm{H}_{16} \mathrm{O}_{2}+\mathrm{Na}\right]^{+}$ 227.1048, found: 227.1039 . 
((5-Methoxy-1-vinyl-1,2,3,4-tetrahydronaphthalen-1-yl)oxy)trimethylsilane (3d). General Procedure for the Protection with a TMS group. A solution of $\mathbf{2 d}(2.86 \mathrm{~g}, 14.0 \mathrm{mmol}), \mathrm{I}_{2}$ (a crystal) in anhydrous $\mathrm{CH}_{2} \mathrm{Cl}_{2}(56 \mathrm{~mL})$ was added dropwise for $5 \mathrm{~min}$ to a solution of HMDS $(2.4 \mathrm{~mL}, 11 \mathrm{mmol})$ in anhydrous $\mathrm{CH}_{2} \mathrm{Cl}_{2}(14 \mathrm{~mL})$. This mixture was stirred for $30 \mathrm{~min}$ at $\mathrm{rt}$ and $\mathrm{Na}_{2} \mathrm{~S}_{2} \mathrm{O}_{3}(4.2 \mathrm{~g})$ was added. The mixture became clear and was stirred for $30 \mathrm{~min}$. The mixture was filtered through a silica pad $\left(5 \times 2 \mathrm{~cm}\right.$ ) using $\mathrm{CH}_{2} \mathrm{Cl}_{2}$ as eluent. The solvent was removed under reduced pressure and the product was purified by flash column chromatography (hexanes/AcOEt, 17:3), giving 3d (1.60 g, 5.79 mmol, $41 \%$ ) as a slightly yellow oil. IR (film) $v / \mathrm{cm}^{-1} 837,1046,1257,1457,1584,2941 ;{ }^{1} \mathrm{H}-\mathrm{NMR}$ (300 MHz, $\left.\mathrm{CDCl}_{3}\right) \delta-0.04(\mathrm{~s}, 9 \mathrm{H}), 1.70-1.85(\mathrm{~m}, 1 \mathrm{H}), 1.87-1.99(\mathrm{~m}, 3 \mathrm{H}), 2.56-2.78(\mathrm{~m}, 2 \mathrm{H}), 3.81(\mathrm{~s}, 3 \mathrm{H}), 5.05$ (dd, $1 \mathrm{H}, J=1.8,16.8), 5.09(\mathrm{dd}, 1 \mathrm{H}, J=1.8,10.5), 6.04$ (dd, $1 \mathrm{H}, J=10.5,16.8), 6.71$ (dd, 1H, $J=1.2,7.8), 7.04(\mathrm{dd}, 1 \mathrm{H}, J=1.2,7.8), 7.13(\mathrm{t}, 1 \mathrm{H}, J=7.8) ;{ }^{13} \mathrm{C}-\mathrm{NMR}\left(75 \mathrm{MHz}, \mathrm{CDCl}_{3}\right) \delta 2.2,18.9$, 23.0, 37.4, 55.3, 76.4, 108.1, 113.0, 120.9, 125.7, 126.1, 141.4, 145.7, 156.6; LRMS m/z (\%) 73 (100), 115 (23), 128 (17), 158 (34), 171 (17), 186 (54), $276\left(\mathrm{M}^{+\bullet}, 11\right), 248$ (40); HRMS (ESI) $\mathrm{m} / z$, calcd for $\left[\mathrm{C}_{16} \mathrm{H}_{24} \mathrm{O}_{2} \mathrm{Si}+\mathrm{Na}\right]^{+}:$299.1443, found: 299.1442 .

((6,7-Dimethoxy-1-vinyl-1,2,3,4-tetrahydronaphthalen-1-yl)oxy)trimethylsilane (3f). The general procedure was followed using 6,7-dimethoxy-1-tetralone (2.12 g, $10.0 \mathrm{mmol})$, THF (17 mL), and $\mathrm{CH}_{2}=\mathrm{CHMgBr}(1 \mathrm{M}$ in THF, $27.2 \mathrm{~mL}, 27.2 \mathrm{mmol})$. A solution of the crude product $(2.69 \mathrm{~g})$ in anhydrous $\mathrm{CH}_{2} \mathrm{Cl}_{2}(10 \mathrm{~mL})$ was added dropwise for $5 \mathrm{~min}$ to a solution of HMDS (1.7 mL, $\left.8.4 \mathrm{mmol}\right)$ and of $\mathrm{I}_{2}$ (a crystal) in anhydrous $\mathrm{CH}_{2} \mathrm{Cl}_{2}(40 \mathrm{~mL})$. This mixture was stirred for $30 \mathrm{~min}$ at $\mathrm{rt}$ and $\mathrm{Na}_{2} \mathrm{~S}_{2} \mathrm{O}_{3}(3.11 \mathrm{~g})$ was added. The mixture became clear and was stirred for $30 \mathrm{~min}$. The mixture was filtered through a silica pad $(5 \times 2 \mathrm{~cm})$ using $\mathrm{CH}_{2} \mathrm{Cl}_{2}$ as eluent. The solvent was removed under reduced pressure and the product was purified by flash column chromatography (hexanes/AcOEt, 3:2), giving 3f, as a white solid (1.81 g, $5.91 \mathrm{mmol}, 59 \%$ ). mp 48.5-49.7 ${ }^{\circ} \mathrm{C}$; IR (film) v/cm ${ }^{-1} 840,910,928,1032,1049,1116$, $1137,1216,1261,1462,1516,2952,3001 ;{ }^{1} \mathrm{H}-\mathrm{NMR}\left(300 \mathrm{MHz}, \mathrm{CDCl}_{3}\right) \delta-0.03$ (s, 9H), $1.71-1.84$ $(\mathrm{m}, 1 \mathrm{H}), 1.87-1.98(\mathrm{~m}, 3 \mathrm{H}), 2.62-2.79(\mathrm{~m}, 2 \mathrm{H}), 3.83(\mathrm{~s}, 3 \mathrm{H}), 3.85(\mathrm{~s}, 3 \mathrm{H}), 5.06(\mathrm{dd}, 1 \mathrm{H}, J=1.8,16.8)$, 5.09 (dd, $1 \mathrm{H}, J=1.8,10.5), 6.02(\mathrm{dd}, 1 \mathrm{H}, J=10.5,16.8), 6.52(\mathrm{~s}, 1 \mathrm{H}), 6.89(\mathrm{~s}, 1 \mathrm{H}) ;{ }^{13} \mathrm{C} \mathrm{NMR}(75 \mathrm{MHz}$, $\left.\mathrm{CDCl}_{3}\right) \delta 2.2,19.8,29.1,38.0,55.7$ (2C), 76.4, 110.7, 111.5, 112.9, 129.4, 132.0, 145.8, 146.8, 148.1; anal. calcd for $\mathrm{C}_{17} \mathrm{H}_{26} \mathrm{O}_{3} \mathrm{Si}$ : C, 66.62; H, 8.55, found: C, 67.03; H, 8.69 (\% H); LRMS m/z (\%) 45 (41), 73 (100), 115 (21), 128 (16), 188 (16), 216 (17), 179 (39), $306\left(\mathrm{M}^{+\bullet}, 6\right)$; HRMS (ESI) $\mathrm{m} / z$, calcd for $\left[\mathrm{C}_{17} \mathrm{H}_{26} \mathrm{O}_{3} \mathrm{Si}+\mathrm{Na}\right]^{+}:$329.1549, found: 329.1552 .

((5-Bromo-1-vinyl-1,2,3,4-tetrahydronaphthalen-1-yl)oxy)trimethylsilane (3g). The general procedure was followed using 5-bromo-1-tetralone (0.788 g, $3.50 \mathrm{mmol})$, THF $(25 \mathrm{~mL})$, and $\mathrm{CH}_{2}=\mathrm{CHMgBr}(1 \mathrm{M}$ in THF, $8.8 \mathrm{~mL}, 8.8 \mathrm{mmol}, 2.5$ equiv). The crude product was protected with a TMS group following the general procedure, but using $\mathrm{HMDS}(0.7 \mathrm{~mL}, 3.2 \mathrm{mmol})$ in $\mathrm{CH}_{2} \mathrm{Cl}_{2}(4 \mathrm{~mL})$, and a solution of the crude alcohol $(1.01 \mathrm{~g})$ and $\mathrm{I}_{2}$ (a crystal) in $\mathrm{CH}_{2} \mathrm{Cl}_{2}(16 \mathrm{~mL})$. The mixture was filtered through a silica pad $(5 \times 2 \mathrm{~cm})$ using hexanes/Et $2 \mathrm{O}(97: 3)$ as eluent, giving $\mathbf{3 g}(0.783 \mathrm{~g}, 2.50 \mathrm{mmol}, 71 \%)$, as slightly yellow oil. IR (film) $v / \mathrm{cm}^{-1} 756,840,900,915,1048,1251,2948 ;{ }^{1} \mathrm{H}-\mathrm{NMR}\left(300 \mathrm{MHz}, \mathrm{CDCl}_{3}\right) \delta$ $-0.02(\mathrm{~s}, 9 \mathrm{H}), 1.77-1.86(\mathrm{~m}, 1 \mathrm{H}), 1.89-2.01(\mathrm{~m}, 3 \mathrm{H}), 2.67-2.82(\mathrm{~m}, 2 \mathrm{H}), 4.99(\mathrm{dd}, 1 \mathrm{H}, J=1.5,17.1)$, $5.12(\mathrm{dd}, 1 \mathrm{H}, J=1.5,10.5), 6.02(\mathrm{dd}, 1 \mathrm{H}, J=10.5,17.1), 7.03(\mathrm{t}, 1 \mathrm{H}, J=7.8), 7.40$ (dd, $1 \mathrm{H}, J=1.2$, 7.8), $7.44(\mathrm{dd}, 1 \mathrm{H}, J=1.2,7.8) ;{ }^{13} \mathrm{C}-\mathrm{NMR}\left(75 \mathrm{MHz}, \mathrm{CDCl}_{3}\right) \delta 2.2,19.2,30.3,37.1,77.2,113.9$, 
124,9, 126.7, 128.1, 131.3, 136.4, 143.0, 145.3; anal. calcd for $\mathrm{C}_{15} \mathrm{H}_{21} \mathrm{BrOSi}$ : C, 55.38; $\mathrm{H}, 6.51$; $\mathrm{Br}$, 24.56, found: C, 55.61; H, 6.55; Br, 24.67; LRMS m/z (\%) 45 (33), 73 (100), 115 (21), 128 (21), 155

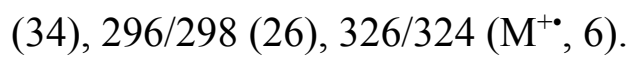

1-Tosyl-4-((trimethylsilyl)oxy)-4-vinyl-1,2,3,4-tetrahydroquinoline (31). The general procedure was followed using 11 (2.41 g, $8.00 \mathrm{mmol})$, THF $(25 \mathrm{~mL})$, and $\mathrm{CH}_{2}=\mathrm{CHMgBr}(1 \mathrm{M}$ in THF, $20.0 \mathrm{~mL}$, $20.0 \mathrm{mmol}, 2.5$ equiv). The crude alcohol was purified by flash column chromatography $\left(\mathrm{CH}_{2} \mathrm{Cl}_{2}\right.$ as eluent), giving the alcohol $(0.631 \mathrm{~g}, 2.00 \mathrm{mmol}, 25 \%)$, as yellow oil. The alcohol was protected following the general procedure, but using HMDS $\left(0.34 \mathrm{~mL}, 1.6 \mathrm{mmol}, 0.8\right.$ equiv) in $\mathrm{CH}_{2} \mathrm{Cl}_{2}(2 \mathrm{~mL})$ and a solution of the alcohol $(0.631 \mathrm{~g}, 2.00 \mathrm{mmol})$ and $\mathrm{I}_{2}$ (a crystal) in $\mathrm{CH}_{2} \mathrm{Cl}_{2}(8 \mathrm{~mL})$. Compound $3 \mathrm{I}$ (0.800 g, $1.99 \mathrm{mmol}, 100 \%)$ was obtained as brown oil. IR (film) v/ $\mathrm{cm}^{-1} 840,1166,1357,2957$; ${ }^{1} \mathrm{H}-\mathrm{NMR}\left(300 \mathrm{MHz}, \mathrm{CDCl}_{3}\right) \delta-0.13(\mathrm{~s}, 9 \mathrm{H}), 1.64-1.82(\mathrm{~m}, 2 \mathrm{H}), 2.37(\mathrm{~s}, 3 \mathrm{H}), 3.86-4.01(\mathrm{~m}, 2 \mathrm{H}), 4.89$ $(\mathrm{dd}, 1 \mathrm{H}, J=1.5,16.8), 5.00(\mathrm{dd}, 1 \mathrm{H}, J=1.5,10.5), 5.66(\mathrm{dd}, 1 \mathrm{H}, J=10.5,16.8), 7.08(\mathrm{td}, 1 \mathrm{H}$, $J=1.2,7.5,11.7), 7.19-7.22(\mathrm{~m}, 2 \mathrm{H}), 7.23-7.27(\mathrm{~m}, 1 \mathrm{H}), 7.32(\mathrm{dd}, 1 \mathrm{H}, J=1.8,11.7), 7.55(\mathrm{dt}, 2 \mathrm{H}$, $J=1.8,8.4), 7.87(\mathrm{dd}, 1 \mathrm{H}, J=0.9,8.4) ;{ }^{13} \mathrm{C}-\mathrm{NMR}\left(75 \mathrm{MHz}, \mathrm{CDCl}_{3}\right) \delta 2.2,21.5,35.2,43.4,73.8$, 114.4, 122.6, 124.1, 127.2 (2C), 128.3, 129.4, 129.6 (2C), 131.8, 136.1, 136.7, 143.7, 143.8; LRMS m/z (\%) 45 (10), 73 (54), 91 (27), 130 (20), 156 (100), 218 (9), 246 (18), $401\left(\mathrm{M}^{+\bullet}, 3\right)$; HRMS (ESI) $m / z$, calcd for $\left[\mathrm{C}_{21} \mathrm{H}_{27} \mathrm{NO}_{3} \mathrm{SSi}+\mathrm{Na}\right]^{+}: 424.1379$, found: 424.1376 .

1,5-Dimethoxy-5-(methoxymethyl)-5,7,8,9-tetrahydro-6H-benzo[7]annulen-6-one $\quad$ (8d). General Procedure for the Ring Expansion of TMS-protected Allylic Alcohols. To a solution of 3d (0.138 g, $0.500 \mathrm{mmol})$ in $\mathrm{MeOH}(2 \mathrm{~mL})$ was added HTIB $(0.490 \mathrm{~g}, 1.25 \mathrm{mmol})$ at $0{ }^{\circ} \mathrm{C}$. The progress of the reaction was monitored by filter paper impregnated with a solution of KI (10\%). The reaction was stirred for $1 \mathrm{~h}$ at this temperature and $1 \mathrm{~h}$ at $\mathrm{rt}$. The reaction was quenched with saturated solution of $\mathrm{NaHCO}_{3}(3 \mathrm{~mL})$. The aqueous phase was extracted with $\mathrm{CH}_{2} \mathrm{Cl}_{2}(3 \times 5 \mathrm{~mL})$. The organic phase was washed with $\mathrm{H}_{2} \mathrm{O}$ and with brine. The organic phase was dried with anhydrous $\mathrm{MgSO}_{4}$, filtered and the solvent was removed under reduced pressure. The residue was purified by flash column chromatography (hexanes/Et $2 \mathrm{O}, 2: 3)$, giving $8 \mathrm{~d}(0.0676 \mathrm{~g}, 0.256 \mathrm{mmol}, 51 \%)$, as yellow oil. IR (film) $v / \mathrm{cm}^{-1} 1079,1098,1469,1581,1718,2834,2935 ;{ }^{1} \mathrm{H}-\mathrm{NMR}\left(300 \mathrm{MHz}, \mathrm{CDCl}_{3}\right) \delta 1.67-1.82(\mathrm{~m}, 1 \mathrm{H})$, 2.06-2.18 (m, 1H), 2.40-2.47 (m, 1H), 2.96 (dtd, 1H, $J=3.3,13.2), 3.19(\mathrm{~s}, 3 \mathrm{H}), 3.34-3.20(\mathrm{~m}, 2 \mathrm{H})$, $3.39(\mathrm{~s}, 3 \mathrm{H}), 3.81(\mathrm{~s}, 3 \mathrm{H}), 3.98(\mathrm{~d}, 1 \mathrm{H}, J=9.6), 4.21(\mathrm{~d}, 1 \mathrm{H}, J=9.6), 6.83-6.89(\mathrm{~m}, 2 \mathrm{H}), 7.19(\mathrm{t}, 1 \mathrm{H}$, $J=8.1) ;{ }^{13} \mathrm{C}-\mathrm{NMR}\left(75 \mathrm{MHz}, \mathrm{CDCl}_{3}\right) \delta 21.6,27.5,39.5,51.2,55.9,59.7,72.4,87.6,111.3,119.3$, 127.0, 129.9, 136.2, 157.0, 210.1; LRMS m/z (\%) 45 (56), 77 (22), 91 (29), 115 (25), 144 (41), 159 (61), 172 (37), 191 (100), 219 (36), $264\left(\mathrm{M}^{+\bullet}, 5\right)$; HRMS (ESI) $m / z$, calcd for $\left[\mathrm{C}_{15} \mathrm{H}_{20} \mathrm{O}_{4}+\mathrm{Na}\right]^{+}$: 287.1259, found: 287.1258 .

Oxidation of $\mathbf{3 f}$ with HTIB. The general procedure for ring expansion was followed, using HTIB ( $0.490 \mathrm{~g}, 1.25 \mathrm{mmol})$, solution of $\mathbf{3 f}(0.153 \mathrm{~g}, 0.500 \mathrm{mmol})$ and of PTSA (0.020 g, $0.12 \mathrm{mmol}, 20 \mathrm{~mol} \%)$ in AcOEt/MeOH $(2: 1,3 \mathrm{~mL})$ at $-72{ }^{\circ} \mathrm{C}$. The residue was purified by flash column chromatography (hexanes/AcOEt, 3:7), giving a mixture of $\mathbf{5 f}$ and $\mathbf{8 f}(0.100 \mathrm{~g}, 0.424 \mathrm{mmol}, 76 \%)$, as yellow oil and $\mathbf{1 2 f}$ (0.015 g, $0.054 \mathrm{mmol}, 10 \%)$, as white solid. 2,3-Dimethoxy-5-(methoxymethyl)-5,7,8,9-tetrahydro$6 H$-benzo[7] annulen-6-one (5f): ${ }^{1} \mathrm{H}-\mathrm{NMR}\left(500 \mathrm{MHz}, \mathrm{CDCl}_{3}\right) \delta 1.88-1.95(\mathrm{~m}, 1 \mathrm{H}), 2.05-2.11(\mathrm{~m}, 1 \mathrm{H})$, 
2.54-2.58 (m, 1H), 2.67-2.72 (m, 1H), 2.84-2.94 (m, 2H), $3.38(\mathrm{~s}, 3 \mathrm{H}), 3.83(\mathrm{dd}, 1 \mathrm{H}, J=6.0,9.0)$, $3.87(\mathrm{~d}, 6 \mathrm{H}, J=2.0), 4.00-4.02(\mathrm{~m}, 1 \mathrm{H}), 4.12(\mathrm{dd}, 1 \mathrm{H}, J=7.5,9.0), 6.64(\mathrm{~s}, 1 \mathrm{H}), 6.71(\mathrm{~s}, 1 \mathrm{H})$; ${ }^{13} \mathrm{C}-\mathrm{NMR}\left(125 \mathrm{MHz}, \mathrm{CDCl}_{3}\right) \delta$ 28.0, 32.6, 43.5, 55.9, 56.1, 56.6, 59.2, 71.2, 111.5, 113.1, 126.6, 133.0, 147.6, 147.8, 209.3; HRMS (ESI) $\mathrm{m} / z$, calcd for $\left[\mathrm{C}_{15} \mathrm{H}_{20} \mathrm{O}_{4}+\mathrm{Na}\right]^{+}:$287.1259, found: 287.1259 . 2,3,5-Trimethoxy-5-(methoxymethyl)-5,7,8,9-tetrahydro-6H-benzo[7]annulen-6-one $\quad(\mathbf{8 f})$ : ${ }^{1} \mathrm{H}-\mathrm{NMR}$ $\left(500 \mathrm{~Hz}, \mathrm{CDCl}_{3}\right) \delta 1.80-1.87(\mathrm{~m}, 1 \mathrm{H}), 2.12-2.19(\mathrm{~m}, 1 \mathrm{H}), 2.44$ (quin, $\left.1 \mathrm{H}, J=5.5\right), 2.63$ (ddd, $1 \mathrm{H}, J=3.5$, 6.5, 14.0), 3.19 (s, 3H), 3.24-3.32 (m, 2H), 3.42 (s, 3H), 3.88 (d, 6H, $J=2.0$ ), 3.98 (d, 1H, $J=10.0), 4.20$ $(\mathrm{d}, 1 \mathrm{H}, J=9.5), 6.62(\mathrm{~s}, 1 \mathrm{H}), 6.67(\mathrm{~s}, 1 \mathrm{H}) ;{ }^{13} \mathrm{C}-\mathrm{NMR}\left(125 \mathrm{MHz}, \mathrm{CDCl}_{3}\right) \delta 28.9,33.2,39.4,51.0,55.8$, 56.1, 59.7, 72.1, 87.5, 110.8, 114.2, 126.3, 134.5, 147.3, 148.6, 209.9; HRMS (ESI) $\mathrm{m} / z$, calcd for $\left[\mathrm{C}_{16} \mathrm{H}_{22} \mathrm{O}_{5}+\mathrm{Na}\right]^{+}: \quad 317.1365$, found: 317.1364. trans-3,4a-Dimethoxy-9-(methoxymethyl)-4a,5,6,7tetrahydro-2 $H$-benzo[7]annulene-2,8(9H)-dione (12f): $\mathrm{mp} 160.4-161.0{ }^{\circ} \mathrm{C}$; IR (film) $\mathrm{v} / \mathrm{cm}^{-1} 1091$, 1170, 1227, 1392, 1451, 1669, 1700, 2937; ${ }^{1} \mathrm{H}-\mathrm{NMR}\left(300 \mathrm{MHz}, \mathrm{CDCl}_{3}\right) \delta 1.46-1.55(\mathrm{~m}, 1 \mathrm{H}), 1.67-1.76$ (m, 1H), 2.30-2.60 (m, 4H), $3.62(\mathrm{dd}, 1 \mathrm{H}, J=7.2,9.6), 3.71(\mathrm{~s}, 3 \mathrm{H}), 3.98(\mathrm{dd}, 1 \mathrm{H}, J=6.6,9.6), 4.34$ (t, $1 \mathrm{H}, J=6.9), 5.64(\mathrm{~s}, 1 \mathrm{H}), 6.23(\mathrm{~d}, 1 \mathrm{H}, J=0.9) ;{ }^{13} \mathrm{C}-\mathrm{NMR}\left(75 \mathrm{MHz}, \mathrm{CDCl}_{3}\right) \delta 17.8,42.6,42.9,50.9$, 52.6, 55.1, 59.2, 69.9, 77.4, 118.7, 128.6, 151.7, 158.0, 180.1, 205.1; LRMS m/z (\%) 39 (49), 51 (76), 65 (44), 77 (84), 91 (100), 103 (42), 115 (57), 131 (42), 149 (51), 161 (54), 177 (65), 192 (40), 205 (60), 220 (96), 233 (26), 248 (43); HRMS (ESI) $m / z$, calcd for $\left[\mathrm{C}_{15} \mathrm{H}_{20} \mathrm{O}_{5}+\mathrm{Na}\right]^{+}:$303.1208, found: 303.1207.

1-Bromo-5-methoxy-5-(methoxymethyl)-5,7,8,9-tetrahydro-6H-benzo[7]annulen-6-one (8g). To a solution of $3 \mathrm{~g}(0.193 \mathrm{~g}, 0.481 \mathrm{mmol})$ and of PTSA $(0.020 \mathrm{~g}, 0.12 \mathrm{mmol}, 24 \mathrm{~mol} \%)$ in $\mathrm{MeOH}(3 \mathrm{~mL})$ was added HTIB $(0.471 \mathrm{~g}, 1.20 \mathrm{mmol})$ at $0{ }^{\circ} \mathrm{C}$. The mixture was stirred for $1 \mathrm{~h}$. The temperature was increased to $\mathrm{rt}$ and the mixture was stirred for $2 \mathrm{~h}$. The temperature was increased to $50{ }^{\circ} \mathrm{C}$ and the mixture was stirred for $3 \mathrm{~h}$. The reaction was quenched with saturated solution of $\mathrm{NaHCO}_{3}(5 \mathrm{~mL})$. The aqueous phase was extracted with $\mathrm{CH}_{2} \mathrm{Cl}_{2}(3 \times 5 \mathrm{~mL})$. The organic phase was washed with $\mathrm{H}_{2} \mathrm{O}$ and with brine. The organic phase was dried with anhydrous $\mathrm{MgSO}_{4}$, filtered and the solvent was removed under reduced pressure. The residue was purified by flash column chromatography (hexanes/AcOEt, 9:1), giving $8 \mathrm{~g}(0.102 \mathrm{~g}, 0.325 \mathrm{mmol}, 65 \%)$, as slightly yellow oil. IR (film) $\mathrm{v} / \mathrm{cm}^{-1}$ 744, 790, 1119, 1437, 1719, 2828, 2932; ${ }^{1} \mathrm{H}-\mathrm{NMR}$ (300 MHz, $\left.\mathrm{CDCl}_{3}\right) \delta 1.78-2.14$ (m, 2H), 2.38-2.48 (m, 1H), 2.99-3.14 (m, 1H), $3.21(\mathrm{~s}, 3 \mathrm{H}), 3.24-3.30(\mathrm{~m}, 2 \mathrm{H}), 3.35(\mathrm{~s}, 3 \mathrm{H}), 3.93(\mathrm{~d}, 1 \mathrm{H}, J=9.6), 4.12$ $(\mathrm{d}, 1 \mathrm{H}, J=9.9), 7.11(\mathrm{t}, 1 \mathrm{H}, J=7.8), 7.31(\mathrm{dd}, 1 \mathrm{H}, J=1.2,7.8), 7.57(\mathrm{dd}, 1 \mathrm{H}, J=1.2,7.8)$; ${ }^{13} \mathrm{C}-\mathrm{NMR}$ $\left(75 \mathrm{MHz} \mathrm{CDCl}_{3}\right) \delta 26.0,30.1,38.6,51.6,59.7,72.3,86.5,125.9,126.9,127.7,133.4,137.7,139.4$, 209.1. LRMS m/z (\%) 45 (62), 89 (18), 115 (34), 128 (100), 209 (16), 220 (17), 239/241 (33), 267/269 (21), 312/314 $\left(\mathrm{M}^{+\bullet}, 5\right)$; HRMS (ESI) $m / z$, calcd for $\left[\mathrm{C}_{14} \mathrm{H}_{17} 79 \mathrm{BrO}_{3}+\mathrm{Na}\right]^{+}: 335.0259$, found: 335.0261, calcd for $\left[\mathrm{C}_{14} \mathrm{H}_{17} 81 \mathrm{BrO}_{3}+\mathrm{Na}\right]^{+}: 337.0238$, found: 337.0230 .

5-Methoxy-5-(methoxymethyl)-1-tosyl-1,2,3,5-tetrahydro-4H-benzo[b]azepin-4-one (81). The reaction was performed as described for $\mathbf{8 g}$, using a solution of $\mathbf{3 l}(0.197 \mathrm{~g}, 0.490 \mathrm{mmol})$ and of PTSA $(0.020 \mathrm{~g}$, $0.12 \mathrm{mmol}, 24 \mathrm{~mol} \%$ ) in $\mathrm{MeOH}(3 \mathrm{~mL})$, and HTIB (0.481 g, $1.23 \mathrm{mmol})$. The residue was purified by flash column chromatography (hexanos/ $\left.\mathrm{AcOEt} / \mathrm{CH}_{2} \mathrm{Cl}_{2}, 5: 1: 4\right)$, giving $\mathbf{8 1}(0.135 \mathrm{~g}, 0.346 \mathrm{mmol}, 69 \%$ ), as slightly yellow solid.mp $100.4-100.7^{\circ} \mathrm{C}$; IR (film) v/cm ${ }^{-1} 1159,1348,1454,1487,1720,2827,2930$; ${ }^{1} \mathrm{H}-\mathrm{NMR}\left(300 \mathrm{MHz}, \mathrm{CDCl}_{3}\right) \delta 2.45(\mathrm{~s}, 3 \mathrm{H}), 2.51-2.58(\mathrm{~m}, 1 \mathrm{H}), 3.06-3.14(\mathrm{~m}, 1 \mathrm{H}), 3.23(\mathrm{~s}, 3 \mathrm{H}), 3.31$ (s, 3H), 3.73 (d, 1H, $J=10.8), 3.83$ (bs, 2H), 4.19 (d, 1H, $J=10.5), 7.29-7.38$ (m, 5H), 7.55-7.57 (m, 
1H), $7.77(\mathrm{dt}, 2 \mathrm{H}, J=1.8,3.9,8.4) ;{ }^{13} \mathrm{C}-\mathrm{NMR}\left(75 \mathrm{MHz}, \mathrm{CDCl}_{3}\right) \delta 21.6,38.8,48.6,52.5,59.6,72.5$, 85.4, 127.5, 127.7 (2C), 128.1, 129.3, 129.5, 129.8 (2C), 137.3 (2C), 144.0 (2C), 205.4; LRMS m/z (\%) 45 (100), 65 (52), 77 (27), 91 (87), 130 (33), $389\left(\mathrm{M}^{+\bullet}, 1\right)$; HRMS (ESI) $\mathrm{m} / z$, calcd for $\left[\mathrm{C}_{20} \mathrm{H}_{23} \mathrm{NO}_{5} \mathrm{~S}+\mathrm{Na}\right]^{+}:$412.1195, found: 412.1182 .

The compounds $\mathbf{5 f}+\mathbf{8 f}(1: 1), \mathbf{8 d}, \mathbf{8 g}, \mathbf{1 2}, \mathbf{1 5}$ and $\mathbf{2 2 I}$ were evaluated in vitro against a panel of nine cell lines [U251 (glioma); UACC-62 (melanoma); MCF-7 (breast); NCI-ADR/RES (ovarian resistant to multiple drugs); 786-0 (kidney); NCI-H460 (lung, non small cells); PC-3 (prostate); HT29 (colon); K562 (leukemia)] kindly provided by Frederick MA (National Cancer Institute, Bethesda, MD, USA) and the immortalized human keratinocytes (HaCat) cell line kindly provided by Prof. Dr. Ricardo Della Coletta (University of Campinas, UNICAMP, Campinas, Brazil). Stock and experimental cultures were grown in medium containing $5 \mathrm{~mL}$ RPMI 1640 (GIBCO BRL) supplemented with 5\% fetal bovine serum (GIBCO BRL). Penicilin/Streptomicin mixture (1000 Um· $\mathrm{L}^{-1}: 1000 \mu \mathrm{g} \cdot \mathrm{mL}^{-1}, 1 \mathrm{~mL} \mathrm{~L}{ }^{-1} \mathrm{RPMI}$ ) was added to the experimental cultures. Cells in 96 -well plates $\left(100 \mu \mathrm{L}\right.$ cells well $\left.{ }^{-1}\right)$ were exposed to sample concentrations in DMSO/RPMI $\left(0.25,2.5,25,250 \mu \mathrm{g} \cdot \mathrm{mL}^{-1}\right)$ in triplicate at $37{ }^{\circ} \mathrm{C}, 5 \%$ of $\mathrm{CO}_{2}$ in air for $48 \mathrm{~h}$. The final DMSO concentration did not affect cell viability. Doxorubicin $\left(0.025\right.$ to $\left.25 \mu \mathrm{g} \cdot \mathrm{mL}^{-1}\right)$ was used as positive control. Before ( $\mathrm{T}_{0}$ plate) and after the sample addition ( $\mathrm{T}_{1}$ plates), cells were fixed with $50 \%$ trichloroacetic acid, and cell proliferation was determined by spectrophotometric quantification $(540 \mathrm{~nm})$ of cellular protein using the sulforhodamine B assay. Using the dose-response curve for each cell line, the concentration that totally inhibits cell growth (TGI, expressed in $\mu \mathrm{M}$ ) was determined through non-linear regression analysis using ORIGIN software version 8.0 (OriginLab Corporation, Northampton, MA, USA, 2007) [63,70].

\section{Conclusions}

In conclusion, a metal-free approach for the synthesis of seven- and eight- membered rings through an iodine(III)-mediated ring expansion reaction was described. The substrates can be easily obtained from readily available starting materials. The amount of the oxidizer and the reaction conditions can be managed to obtain different products. Moreover, a short route to the synthesis of medium-ring lactones was developed. The antiproliferative activity of new seven-membered ring compounds was evaluated, and the results showed compound $\mathbf{1 2 f}$ as having a moderated citostatic effect. The results herein described have great potential for application in the chemical synthesis of seven-membered rings.

\section{Supplementary Materials}

Supplementary materials can be accessed at: http://www.mdpi.com/1420-3049/20/01/1475/s1.

\section{Acknowledgments}

The authors thank R.S. Vasconcelos for initial experiments. The authors thank FAPESP (2010/16042-6 and 2012/10568-1), CAPES and CNPq for financial support. 


\section{Author Contributions}

The project was conceived by Silva, L.F., Jr. The experiment design concerning the chemical part was realized by Silva, L.F., Jr. and Silva, S.B.L. and the experiments related with the antiproliferative activity were idealized by Torre, A.D.; Carvalho, J.E. and Ruiz, A.L.T.G. The chemical experiments were performed by Silva, S.B.L. and the antiproliferative ones by Torre, A.D. and Ruiz, A.L.T.G. All the authors contributed in the discussion of the results and in the manuscript preparation.

\section{Conflicts of Interest}

The authors declare no conflict of interest.

\section{References}

1. Kleinke, A.S.; Webb, D.; Jamison, T.F. Recent Progress in the Synthesis of Oxepanes and Medium Ring Ethers. Tetrahedron 2012, 68, 6999-7018.

2. Sharma, A.; Appukkuttan, P.; van der Eycken, E. Microwave-Assisted Synthesis of Medium-Sized Heterocycles. Chem. Commun. 2012, 48, 1623-1637.

3. Majumdar, K.C. Regioselective Formation of Medium-Ring Heterocycles of Biological Relevance by Intramolecular Cyclization. RSC Adv. 2011, 1, 1152-1170.

4. Majumdar, K.C.; Chattopadhyay, B. New Synthetic Strategies for Medium-Sized and Macrocyclic Compounds by Palladium-Catalyzed Cyclization. Curr. Org. Chem. 2009, 13, 731-757.

5. Chattopadhyay, S.K.; Karmakar, S.; Biswas, T.; Majumdar, K.C.; Rahaman, H.; Roy, B. Formation of Medium-Ring Heterocycles by Diene and Enyne Metathesis. Tetrahedron 2007, 63, 3919-3952.

6. Lopez, F.; Mascarenas, J.L. The Oxygen-Bridge Templating Approach to Eight- and Nine-Membered Carbocycles: Recent Developments Based on Catalytic Reactions. Chem. Eur. J. 2007, 13, 2172-2178.

7. Snyder, N.L.; Haines, H.M.; Peczuh, M.W. Recent Developments in the Synthesis of Oxepines. Tetrahedron 2006, 62, 9301-9320.

8. Michaut, A.; Rodriguez, J. Selective Construction of Carbocyclic Eight-Membered Rings by Ring-Closing Metathesis of Acyclic Precursors. Angew. Chem. Int. Ed. 2006, 45, 5740-5750.

9. Nakamura, I.; Yamamoto, Y. Transition-metal-catalyzed reactions in heterocyclic synthesis. Chem. Rev. 2004, 104, 2127-2198.

10. Yet, L. Metal-Mediated Synthesis of Medium-Sized Rings. Chem. Rev. 2000, 100, 2963-3007.

11. Yet, L. Free Radicals in the Synthesis of Medium-Sized Rings. Tetrahedron 1999, 55, 9349-9403.

12. Hoberg, J.O. Synthesis of Seven-Membered Oxacycles. Tetrahedron 1998, 54, 12631-12670.

13. Bauer, R.A.; Wenderski, T.A.; Tan, D.S. Biomimetic Diversity-Oriented Synthesis of Benzannulated Medium Rings via Ring Expansion. Nat. Chem. Biol. 2013, 9, 21-29.

14. Hussain, A.; Yousufb, S.K.; Mukherjee, D. Importance and Synthesis of Benzannulated Medium-Sized and Macrocyclic Rings (BMRs). RSC Adv. 2014, 4, 43241-43257.

15. Illuminati, G.; Mandolini, L. Ring-Closure Reactions of Bifunctional Chain Molecules. Acc. Chem. Res. 1981, 14, 95-102. 
16. Crimmins, M.T.; Choy, A.L. An Asymmetric Aldol-Ring-Closing Metathesis Strategy for the Enantioselective Construction of Oxygen Heterocycles: An Efficient Approach to the Enantioselective Synthesis of (+)-Laurencin. J. Am. Chem. Soc. 1999, 121, 5653-5660.

17. Trost, B.M.; Xie, J. Palladium-Catalyzed Asymmetric Ring Expansion of Allenylcyclobutanols: An Asymmetric Wagner-Meerwein Shift. J. Am. Chem. Soc. 2006, 128, 6044-6045.

18. Waters, S.P.; Tian, Y.; Li, Y.M.; Danishefsky, S.J. Total Synthesis of (-)-Scabronine G, an Inducer of Neurotrophic Factor Production. J. Am. Chem. Soc. 2005, 127, 13514-13515.

19. Kantorowski, E.J.; Kurth, M.J. Expansion to Seven-Membered Rings. Tetrahedron 2000, 56, 4317-4353.

20. Kim, S.; Uh, K.H. Mercurinium Ion Mediated Ring Expansion of 1-Alkenyl-1-Cycloalkanols. Tetrahedron Lett. 1992, 33, 4325-4328.

21. Silva, L.F., Jr.; Carneiro, V.M.T. Thallium(III) in Organic Synthesis. Synthesis 2010, 1059-1074.

22. Kim, S.; Uh, K.H. Thallium Ion Mediated Ring Expansion of 1-Trimethylsilyloxy-1alkenylcycloalkanes to a-exo-Methylenecycloalkanones. Tetrahedron Lett. 1996, 37, 3865-3866.

23. Silva, L.F., Jr.; Olofsson, B. Hypervalent Iodine Reagents in the Total Synthesis of Natural Products. Nat. Prod. Rep. 2011, 28, 1722-1754.

24. Zhdankin, V.V.; Stang, P.J. Chemistry of Polyvalent Iodine. Chem. Rev. 2008, 108, 5299-5358.

25. Wirth, T. Hypervalent Iodine Chemistry in Synthesis: Scope and New Directions. Angew. Chem. Int. Edit. 2005, 44, 3656-3665.

26. Moriarty, R.M. Organohypervalent Iodine: Development, Applications, and Future Directions. J. Org. Chem. 2005, 70, 2893-2903.

27. Singh, F.V.; Wirth, T. Oxidative Rearrangements with Hypervalent Iodine Reagents. Synthesis 2013, 45, 2499-2511.

28. Silva, L.F., Jr. Hypervalent Iodine-Mediated Ring Contraction Reactions. Molecules 2006, 11, 421-434.

29. Varvoglis, A. Hypervalent Iodine in Organic Synthesis; Academic Press: London, UK, 1997.

30. Wirth, T. Topics in Current Chemistry. In Hypervalent Iodine Chemistry-Modern Developments in Organic Synthesis, 1st ed.; Springer: Berlin, Germany, 2003; Volume 224, pp. 1-264.

31. Justik, M.W.; Koser, G.F. Oxidative Rearrangements of Arylalkenes with Hydroxy(tosyloxy)iodo Benzene in 95\% Methanol: A General, Regiospecific Synthesis of $\alpha$-Aryl Ketones. Tetrahedron Lett. 2004, 45, 6159-6163.

32. Justik, M.W.; Koser, G.F. Application of Hydroxy(tosyloxy)iodo Benzene in the Wittig-Ring Expansion Sequence for the Synthesis of $\beta$-Benzocycloalkenones from $\alpha$-Benzocycloalkenones. Molecules 2005, 10, 217-225.

33. Chavan, S.P.; Khatod, H.S. Enantioselective Synthesis of the Essential Oil and Pheromonal Component Ar-Himachalene by a Chiral Pool and Chirality Induction Approach. Tetrahedron-Asymmetry 2012, 23, 1410-1415.

34. Silva, L.F., Jr.; Vasconcelos, R.S.; Nogueira, M.A. Iodine(III)-Promoted Ring Expansion of 1-Vinylcycloalkanol Derivatives: A Metal-Free Approach Toward Seven-Membered Rings. Org. Lett. 2008, 10, 1017-1020.

35. Schmidt, B. Ruthenium-Catalyzed Olefin Metathesis Double-Bond Isomerization Sequence. J. Org. Chem. 2004, 69, 7672-7687. 
36. Karimi, B.; Golshani, B. Mild and Highly Efficient Method for the Silylation of Alcohols Using Hexamethyldisilazane Catalyzed by Iodine under Nearly Neutral Reaction Conditions. J. Org. Chem. 2000, 65, 7228-7230.

37. Johnstone, R.A.W.; Rose, M.E. Rapid, Simple, and Mild Procedure for Alkylation of Phenols, Alcohols, Amides and Acids. Tetrahedron 1979, 35, 2169-2173.

38. Yusubov, M.S.; Wirth, T. Solvent-Free Reactions with Hypervalent Iodine Reagents. Org. Lett. 2005, 7, 519-521.

39. D’Souza, A.M.; Paknikar, S.K.; Dev, V.; Beauchamp, P.S.; Kamat, S.P. Biogenetic-Type Synthesis of (+)-Cymbodiacetal, a Constituent of Cymbopogon Martinii. J. Nat. Prod. 2004, 67, 700-702.

40. Rocha, D.F.O.; Hamilton, K.; Goncalves, C.C.S.; Machado, G.; Marsaioli, A.J. 6-Alkyl-3,4dihydro-2H-pyrans: Chemical Secretion Compounds in Neotropical Harvestmen. J. Nat. Prod. 2011, 74, 658-663.

41. Ferraz, H.M.C.; Bombonato, F.I.; Longo, L.S. Synthetic Approaches to Naturally Occurring Ten-Membered-Ring Lactones. Synthesis 2007, 3261-3285.

42. Rousseau, G. Medium Ring Lactones. Tetrahedron 1995, 51, 2777-2849.

43. Silva, L.F., Jr.; Sousa, R.M.F.; Ferraz, H.M.C.; Aguilar, A.M. Thallium Trinitrate-Mediated Ring Contraction of 1,2-Dihydronaphthalenes: The Effect of Electron-Donating and Electron-Withdrawing Groups. J. Braz. Chem. Soc. 2005, 16, 1160-1173.

44. Silva, L.F., Jr.; Siqueira, F.A.; Pedrozo, E.C.; Vieira, F.Y.M.; Doriguetto, A.C. Iodine(III)-Promoted Ring Contraction of 1,2-Dihydronaphthalenes: A Diastereoselective Total Synthesis of $( \pm)$-Indatraline. Org. Lett. 2007, 9, 1433-1436.

45. Siqueira, F.A.; Ishikawa, E.E.; Fogaca, A.; Faccio, A.T.; Carneiro, V.M.T.; Soares, R.R.S.; Utaka, A.; Tebeka, I.R.M.; Bielawski, M.; Olofsson, B.; et al. Metal-Free Synthesis of Indanes by Iodine(III)-Mediated Ring Contraction of 1,2-Dihydronaphthalenes. J. Braz. Chem. Soc. 2011, 22, 1795-1807.

46. Ferraz, H.M.C.; Aguilar, A.M.; Silva, L.F. Model Studies Toward the Synthesis of Natural Indans Utilizing a Thallium(III)-Mediated Ring-Contraction Reaction. Synthesis 2003, 1031-1034.

47. Dohi, T.; Ito, M.; Yamaoka, N.; Morimoto, K.; Fujioka, H.; Kita, Y. Hypervalent Iodine(III): Selective and Efficient Single-Electron-Transfer (SET) Oxidizing Agent. Tetrahedron 2009, 65, 10797-10815.

48. Kita, Y.; Egi, M.; Ohtsubo, M.; Saiki, T.; Okajima, A.; Takada, T.; Tohma, H. Hypervalent Iodine(III)-Induced Intramolecular Cyclization Reaction of Substituted Phenol Ethers with an Alkyl Azido Side-Chain: A Novel and Efficient Synthesis of Quinone Imine Derivatives. Chem. Pharm. Bull. 1999, 47, 241-245.

49. Tankard, M.H.; Whitehurst, J.S. Ethoxyethynyl Carbinol- $\alpha \beta$-Unsaturated Ester ConversionStereomutation Accompanying a Selenium Dioxide Oxidation. Tetrahedron 1974, 30, 451-454.

50. Ahmad, A.; Silva, L.F., Jr. Synthesis of Chromanes and $4 H$-Chromenes: Exploring the Oxidation of 2H-Chromenes and Dihydro-1-benzoxepines by Hypervalent Iodine(III). Synthesis 2012, 44, 3671-3677.

51. Liu, P.; Liu, S.J.; Zhang, J.Z.; Tian, G.R. Selective Oxidation of Sulfides to Sulfoxides with Poly 4-Hydroxy(tosyloxy)iodo Styrene. Synth. Commun. 2005, 35, 3173-3177. 
52. So, M.; Kotake, T.; Matsuura, K.; Inui, M.; Kamimura, A. Concise Synthesis of 2-Benzazepine Derivatives and Their Biological Activity. J. Org. Chem. 2012, 77, 4017-4028.

53. Kouznetsov, V.; Palma, A.; Ewert, C. Synthesis and Applicability of Partially Reduced 2-Benzazepines. Curr. Org. Chem. 2001, 5, 519-551.

54. Grunewald, G.L.; Dahanukar, V.H.; Criscione, K.R. Effects of a 3-Alkyl-, 4-Hydroxy- and/or 8-Aromatic-Substituent on the Phenylethanolamine $N$-Methyltransferase Inhibitor Potency and $\alpha_{2}$-Adrenoceptor Affinity of 2,3,4,5-Tetrahydro-1H-2-Benzazepines. Bioorg. Med. Chem. 2001, 9 , 1957-1965.

55. Johnson, P.D.; Aristoff, P.A.; Zurenko, G.E.; Schaadt, R.D.; Yagi, B.H.; Ford, C.W.; Hamel, J.C.; Stapert, D.; Moerman, J.K. Synthesis and Biological Evaluation of Benzazepine Oxazolidinone Antibacterials. Bioorg. Med. Chem. Lett. 2003, 13, 4197-4200.

56. Kukla, M.J.; Breslin, H.J.; Diamond, C.J.; Grous, P.P.; Ho, C.Y.; Miranda, M.; Rodgers, J.D.; Sherrill, R.G.; de Clercq, E.; Pauwels, R.; et al. Synthesis and Anti-HIV-1 Activity of 4,5,6,7-Tetrahydro-5-Methylimidazo[4,5,1-jk][1,4]benzodiazepin-2(1H)-one (TIBO) Derivatives. J. Med. Chem. 1991, 34, 3187-3197.

57. Qadir, M.; Cobb, J.; Sheldrake, P.W.; Whittall, N.; White, A.J.P.; Hii, K.K.; Horton, P.N.; Hursthouse, M.B. Conformation Analyses, Dynamic Behavior and Amide Bond Distortions of Medium-Sized Heterocycles. 1. Partially and Fully Reduced 1-Benzazepines. J. Org. Chem. 2005, $70,1545-1551$.

58. Boeglin, D.; Bonnet, D.; Hibert, M. Solid-Phase Preparation of a Pilot Library Derived from the 2,3,4,5-Tetrahydro-1H-benzo[b]Azepin-5-amine Scaffold. J. Comb. Chem. 2007, 9, 487-500.

59. Seto, M.; Aikawa, K.; Miyamoto, N.; Aramaki, Y.; Kanzaki, N.; Takashima, K.; Kuze, Y.; Iizawa, Y.; Baba, M.; Shiraishi, M. Highly Potent and Orally Active CCR5 Antagonists as Anti-HIV-1 Agents: Synthesis and Biological Activities of 1-Benzazocine Derivatives Containing a Sulfoxide Moiety. J. Med. Chem. 2006, 49, 2037-2048.

60. Abonia, R.; Cuervo, P.; Insuasty, B.; Quiroga, J.; Nogueras, M.; Cobo, J. A Simple Two-Step Sequence for the Synthesis of Novel 4-Aryl-4,5-dihydro-6H-[1,3]dioxolo[4,5- $h]$ pyrrolo[1,2a][1]benzazepin-6-ones from 6-Amino-3,4-methylenedioxyacetophenone Eur. J. Org. Chem. 2008, 4684-4689.

61. Iqbal, N.; Fiksdahl, A. Gold(I)-Catalyzed Benz[c]azepin-4-ol Synthesis by Intermolecular 5+2 Cycloaddition. J. Org. Chem. 2013, 78, 7885-7895.

62. Ito, H.; Harada, T.; Ohmiya, H.; Sawamura, M. Intramolecular Hydroamination of Alkynic Sulfonamides Catalyzed by a Gold-Triethynylphosphine Complex: Construction of Azepine Frameworks by 7-Exo-Dig Cyclization. Beilstein J. Org. Chem. 2011, 7, 951-959.

63. Monks, A.; Scudiero, D.; Skehan, P.; Shoemaker, R.; Paull, K.; Vistica, D.; Hose, C.; Langley, J.; Cronise, P.; Vaigrowolff, A.; et al. Feasibility of a High-Flux Anticancer Drug Screen Using a Diverse Panel of Cultured Human Tumor-Cell Lines. J. Natl. Cancer Inst. 1991, 83, 757-766.

64. Collins, J.M. DTP-Developmental Therapeutics Program NCI/NIH. Compare Methodology 2000. Available online: http://dtp.nci.nih.gov/docs/compare/compare_methodology.html (accessed on 12 January 2015).

65. Fouche, G.; Cragg, G.M.; Pillay, P.; Kolesnikova, N.; Maharaj, V.J.; Senabe, J. In Vitro Anticancer Screening of South African Plants. J. Ethnopharm. 2008, 119, 455-461. 
66. Seyferth, D. Di-n-butyldivinyltin [Tin, dibutyldivinyl-]. Org. Synth. Coll. 1963, 4, 258.

67. Pagliero, R.J.; Pierini, A.B.; Brun, R.; Mazzieri, M.R. Design, Synthesis and 3-D Characterization of 1-Benzenesulfonyl-1,2,3,4-Tetrahydroquinolinesas Lead Scaffold for Antiparasitic Drug. Lett. Drug Des. Discov. 2010, 7, 461-470.

68. Catino, A.J.; Nichols, J.M.; Choi, H.; Gottipamula, S.; Doyle, M.P. Benzylic Oxidation Catalyzed by Dirhodium(II,III) Caprolactamate. Org. Lett. 2005, 7, 5167-5170.

69. Braunholtz, J.T.; Mann, F.G. Cyclic Keto-Amines. Part II. The Preparation and Spectroscopic Characteristics of Substituted 1:2:3:4-Tetrahydro-4-oxoquinolines. J. Chem. Soc. 1957, 4166-4173.

70. Shoemaker, R.H. The NCI60 Human Tumour Cell Line Anticancer Drug Screen. Nat. Rev. Cancer 2006, 6, 813-823.

Sample Availability: Not available.

(C) 2015 by the authors; licensee MDPI, Basel, Switzerland. This article is an open access article distributed under the terms and conditions of the Creative Commons Attribution license (http://creativecommons.org/licenses/by/4.0/). 